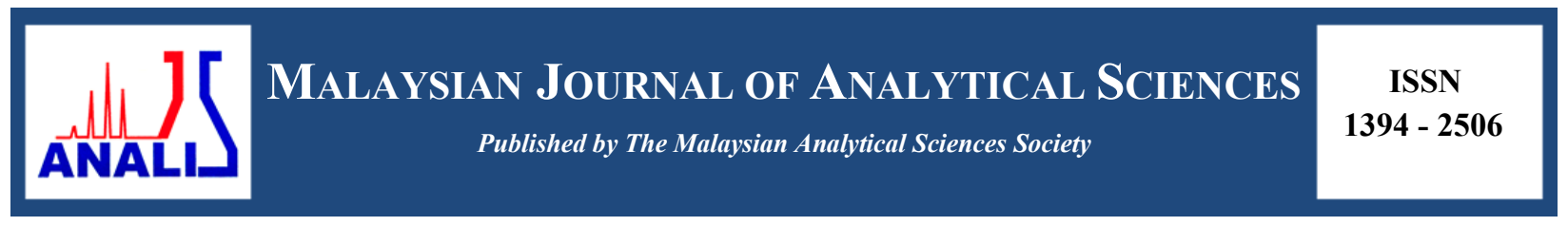

\title{
RESPONSE SURFACE METHODOLOGY ON THE EFFECTS OF SODA - ANTHRAQUINONE PULPING CONDITIONS ON OIL PALM EMPTY FRUIT BUNCHES PULP PROPERTIES
}

\author{
(Kaedah Gerak Balas Permukaan Terhadap Kesan Faktor-Faktor Pemulpaan Soda-Antrakuinon \\ Ke Atas Sifat-sifat Gentian Tandan Buah Kosong Kelapa Sawit) \\ Nurul Husna Mohd Hassan ${ }^{1 *}$, Mazlan Ibrahim², Nor Yuziah Mohd Yunus ${ }^{1}$ \\ ${ }^{I}$ School of Wood Industry, Faculty of Applied Sciences, \\ Universiti Teknologi MARA, Cawangan Pahang, Kampus Jengka, 26400 Bandar Tun Abdul Razak, Pahang \\ ${ }^{2}$ School of Industrial Technology, \\ Universiti Sains Malaysia, 11800 USM Pulau Pinang, Malaysia \\ *Corresponding author: nurulhusna@uitm.edu.my
}

Received: 15 November 2016; Accepted: 29 January 2018

\begin{abstract}
Effects of soda-antrhraquinone (soda-AQ) pulping conditions on pulp properties of oil palm empty fruit bunches were studied by using response surface methodology (RSM) based on central composite design (CCD). Alkali charge (A), pulping temperature (T) and pulping time $(\mathrm{t})$ were the pulping factors studied, with their ranges between $20-30 \%, 160-180{ }^{\circ} \mathrm{C}$ and $60-120$ minutes, respectively. Pulp properties evaluated based on total yield (35.37 - 58.87\%), screened yield (30.37 - 56.07\%), Kappa number $(6-16)$ and viscosity $(5.43-16.02 \mathrm{cP})$. The effect of soda-AQ pulping conditions on oil palm empty fruit bunches fibers was clearly elucidated by the regression model obtained. The generated mathematical relationship showed that the optimum pulping condition was $27.30 \%$ alkali charge, temperature $160{ }^{\circ} \mathrm{C}$ at 60 minutes. This combination of mild pulping conditions level produced: total yield (55.54\%), screened yield (53.20\%), Kappa number (10) and viscosity (12.02 cP).
\end{abstract}

Keywords: oil palm empty fruit bunches, pulp properties, response surface methodology

\begin{abstract}
Abstrak
Kesan faktor-faktor pemulpaan soda-antrakuinon ke atas sifat-sifat gentian tandan buah kosong kelapa sawit telah dikaji dengan menggunakan kaedah gerak balas permukaan (RSM) berasaskan rekabentuk komposit berpusat (CCD). Julat faktor-faktor pemulpaan iaitu cas alkali (A), suhu pemulpaan (T) dan masa pemulpaan (t) adalah antara $20-30 \%, 160-180{ }^{\circ} \mathrm{C}$ dan $60-120$ minit. Sifat-sifat gentian yang dinilai adalah berdasarkan jumlah keseluruhan $(35.37-58.87 \%)$, hasil saringan $(30.37-56.07 \%)$, nombor Kappa $(6-16)$ dan kelikatan $(5.43-16.02 \mathrm{cP})$. Pengaruh faktor-faktor pemulpaan soda-AQ ke atas gentian tandan buah kosong kelapa sawit dapat dijelaskan berdasarkan model regrasi yang diperolehi. Melalui persamaan matematik yang terhasil, pemulpaan optimum berlaku apabila faktor-faktor pemulpaan iaitu cas alkali, suhu pemulpaan dan masa pemulpaan diselaraskan pada $27.3 \%, 160{ }^{\circ} \mathrm{C}$ dan 60 minit. Penggunaan kombinasi aras faktor pemulpaan yang rendah ini dapat menghasilkan hasil keseluruhan (55.54\%), hasil penskrinan (53.20\%), nombor Kappa (10) dan kelikatan (12.02 cP).
\end{abstract}

Kata kunci: tandan buah kosong kelapa sawit, sifat-sifat gentian, kaedah gerak balas permukaan 


\section{Nurul Husna et al: RESPONSE SURFACE METHODOLOGY ON THE EFFECTS OF SODA - ANTHRAQUINONE PULPING CONDITIONS ON OIL PALM EMPTY FRUIT BUNCHES PULP PROPERTIES}

\section{Oil Palm Industry}

\section{Introduction}

Oil palm tree was first introduced for aesthetic and decorative nature at Botanical Garden of Singapore in 1870 and soon has created interest for its commercial exploits. The first two chosen plantation locations were Tenamaran and Elmina Estate, in Kuala Selangor, Malaysia. Subsequently, early 90's had shown the establishment of large plantation areas in Sumatera and Malaysia, by using the palm oil seeds brought over by commercial labourer from Southern America. Today, oil palms are planted commercially in Africa, South East Asia, Pacific Island and Southern America. This industry has many vital roles and the planting activities increase after World War II resulting from world demand and world's fats and oils price stabilization [1].

In Malaysia, the development of oil palm industry is slower, as more emphasis is given towards rubberwood plantation as major export product.The situation changes in 1960's, as the price of the rubber dropped due to the synthetic rubber introduction [2]. Subsequently, Malaysian Government had initiated a major agricultural development program in order to reduce dependency on singular commodity rubber as export income contributor. This led to the opening of newland for oil palm planting and when a rubber estate reached maturity, it was replanted with oil palm. This activities had contributed to rapid increase in oil palm hectarage in a short time. The plantation area surpassed 2 million hectares in 1990 and currently reached 3.8 million hectares, which capable of delivering more than 18.6 million tons crude palm oil. Entering the new millennium era, Malaysia was covered by 3.38 million hectares of oil palm plantations [3, 4, 5]. By 2014, Malaysia has recorded a staggering 5.39 million hectares of oil palm plantations [6], an increase of $11.0 \%$ from the previous 4.85 million hectares in 2010 [7]. Malaysia's total land mass is 32.98 million hectares [8], which equivalent to $16 \%$ of the land that is occupied with oil palm plantation. Mohd Fahmi et al. [7] reported the current situation related to the oil palm industry in Malaysia; the availability of oil palm waste and its utilization through thermochemical conversion, with specific regards to the liquefaction process.

\section{Oil palm lignocellulosic}

Oil palm, Elaeis guineensis, is originated from South Africa and was introduced to South East Asian countries especially Malaysia and Indonesia and the oil is obtained from its fruits [9]. Malaysia is the largest palm oil producer by covering $51 \%$ of world oil palm production [10]. However, in 2007, Indonesia had overtaken Malaysia due to the rapid expansion of oil palm plantations in the region. Nevertheless, Malaysia still held the title as the world's largest crude palm oil exporter [11]. When combined, these neighboring countries had accounted for more than $80 \%$ of the global palm oil supply annually $[12,13]$

After 20 to 25 years, the palm oil fruit production will reduce and need to be cut down for re-planting. Re-planting activities lead to the increase of the abundance of palm oil trunks (OPT) and oil palm frond (OPF). As more plantations reached the limit of its economic production cycle, re-planting activities are expected to increase in the near future. Thus, the disposal of huge volume of palm oil trunks and fronds will become a serious matter as activities during harvering also yield fronds.

In oil palm mills, by-products of oil extraction activities generate palm kernel shell (PKS), empty fruit bunches (EFB), pressed fruit fibers (PFF) and palm oil mill effluent (POME). The oil palm mills waste by-product amount was quoted to be in the range of 70-80 million tons per annum, where only $10 \%$ of the total biomass was utilized and the rest was discarded as wastes [14].These by-products could and have been re-routed to various agronomic uses and mills. These wastes ended up in low value-added activities such as being supplement in ruminant feed, burning material, or would be burnt in the plantation area [4]. The fronds obtained from continuous pruning in plantation are used as interrows coverage [1].Except for POME, the rest of the wastes have high content of fibers [7] and are suitable to be used as the raw material for pulp and paper industry.

\section{Soda-anthraquinone pulping}

According to Eckett et al. [15], soda pulping without AQ gave lower yield and lower viscosity compared to kraft pulping. It utilized $40 \%$ more alkali and $100 \%$ higher $\mathrm{H}$ factor to attain the targeted kappa number. The addition of $0.1 \%$ AQ during soda cooking had reduced $\mathrm{H}$ factor to kraft level, but only with the use of higher alkali percentage. Further AQ addition to $0.15 \%$ will reduce alkali usage and improve yield and viscosity. In both instances, the soda 
usage is still higher than kraft. With AQ addition above $0.35 \%$, soda reduction is no longer proportional to AQ dosage and the reaction level approached an equilibium state.

The application of anthraquinone (AQ) as a pulping catalyst has been well documented in scientific studies and mill applications. AQ is known to increase the rate of delignification, enabling a reduction in pulping time, temperature, or chemical charge and an increase in pulp yield. However, Hart \& Rudie also highlighted that due to unknown health risk, recently, many pulp and paper companies had decided to stop using AQ in the production of direct food contact products [16].

This study aims to focus on EFB as the raw material for pulp and paper production based on the abundant availability of oil palm waste material produced from the oil palm harvesting. The usage of more environmentally chemical pulping process by using soda pulping with AQ was chosen for EFB pulp production, due to its low lignin content as compared to wood materials. With the aid of Response Surface Methology (RSM) Experimental Design, three pulping parameters (alkali percentage, pulping temperature and pulping time) were optimized to find the best pulping conditions combination for EFB fibers. The pulping conditions model can be used to predict the most suitable pulping conditions to be used based on the desired pulp properties.

\section{Raw material preparation}

\section{Materials and Methods}

The raw material used in this study is empty fruit bunches (EFB) obtained from SABUTEK Sdn. Bhd., Teluk Intan, Perak in the form of fibers. The EFB was soaked overnight and washed with water to remove debris such as soil and dust. The fibres were then sun-dried until constant moisture content between $11-12 \%$.

\section{Soda-anthraquinone pulping: Experimental design by response surface methodology}

Sodium hydroxide $(\mathrm{NaOH})$ solution, water and $\mathrm{AQ}$ were added to $300 \mathrm{~g}$ of EFB fiber placed in a Rotary Digester. The digester temperature was increased from room temperature to pulping temperature within 90 minutes. This was done to evenly mix $\mathrm{NaOH}$ solution and EFB fiber prior to the delignification process. Then, the mixture underwent pulping reaction for the selected duration (Table 1). Upon pulping process completion, the pulp was washed under running water to remove all the black liquor. The washed pulp was screened to remove uncooked EFB and any debris. Measurements were taken and recorded throughout the process to determine the pulp moisture content, screened yield, rejected and total yield.

Response surface methodology (RSM) was used in the research to identify the optimum pulping factors. The evaluated factors were pulping temperature $\left(160-180{ }^{\circ} \mathrm{C}\right)$, pulping time $(60-120$ minutes $)$ and active alkali $(20-$ $30 \%$ ). The fixed factors were time of 90 minutes to reach pulping temperature, AQ percentage of $0.1 \%$ with respect to oven dried EFB and EFB fiber of $300 \mathrm{~g}$ for each pulping batch.The pulping process followed combinations stated in Table 1. Based on this program design, 20 experiments were done by following the experimental sequencing. This sequencing allows completely randomized pulping process.

Table 1. Sequencing of soda-anthraquinone pulping

\begin{tabular}{llccc}
\hline \multirow{2}{*}{ Run } & \multirow{2}{*}{ Experiment } & \multicolumn{3}{c}{ Pulping Parameters } \\
\cline { 3 - 5 } & & Temperature (T), ${ }^{\mathbf{0}} \mathbf{C}$ & Time (t), min & Alkali (A), \% \\
\hline 1 & 4 & 160 & 60 & 20 \\
2 & 19 & 180 & 60 & 20 \\
3 & 6 & 160 & 120 & 20 \\
4 & 8 & 180 & 120 & 20 \\
5 & 2 & 160 & 60 & 30 \\
6 & 7 & 180 & 60 & 30 \\
7 & 1 & 160 & 120 & 30 \\
8 & 18 & 180 & 120 & 30 \\
\hline
\end{tabular}


Nurul Husna et al: RESPONSE SURFACE METHODOLOGY ON THE EFFECTS OF SODA ANTHRAQUINONE PULPING CONDITIONS ON OIL PALM EMPTY FRUIT BUNCHES PULP PROPERTIES

Table 1 (cont'd). Sequencing of soda-anthraquinone pulping

\begin{tabular}{llccc}
\hline \multirow{2}{*}{ Run } & \multirow{2}{*}{ Experiment } & \multicolumn{3}{c}{ Pulping Parameters } \\
\cline { 3 - 5 } & & Temperature (T), ${ }^{\mathbf{0}} \mathbf{C}$ & Time (t), min & Alkali (A), \% \\
\hline 9 & 9 & 153 & 90 & 25 \\
10 & 5 & 187 & 90 & 25 \\
11 & 20 & 170 & 40 & 25 \\
12 & 15 & 170 & 141 & 25 \\
13 & 17 & 170 & 90 & 16.6 \\
14 & 3 & 170 & 90 & 33.4 \\
15 & 12 & 170 & 90 & 25 \\
16 & 13 & 170 & 90 & 25 \\
17 & 14 & 170 & 90 & 25 \\
18 & 16 & 170 & 90 & 25 \\
19 & 11 & 170 & 90 & 25 \\
20 & 10 & 170 & 90 & 25 \\
\hline
\end{tabular}

Pulp properties determination: Yield determination

Washed pulp was wringed, weighted and the moisture content was determined with a moisture content analyser. Total yield percentage was calculated using equation 1 [17].

Total yield, $\%=\frac{\text { Weight of oven dried (o.d.) pulp }}{\text { Weight of o.d. raw material, } g} \times 100$

Then, the pulp was screened by using Sommerville Fractionator screener. After screening, screened pulp was spin dried, weighted and moisture content was determined. Total screened yield percentage was calculated using equation $2[18]$.

$$
\text { Screened yield, } \%=\frac{\text { Weight of o.d. screened pulp, } g \times 100}{\text { Weight of o.d. raw material, } g}
$$

Reject yield was determined from collected rejects on screener plate. They were oven dried at $105 \pm 3^{\circ} \mathrm{C}$ to a constant weight. Reject percentage was calculated based on equation 3 [19].

$$
\text { Reject yield, } \%=\frac{\text { Weight of o.d. rejects, } g}{\text { Weight of o.d. raw material, } g} \times 100
$$

\section{Kappa number}

Kappa number qualitatively or indirectly determines the lignin content in pulp. It was verified according to TAPPI T236 cm-85[18]. Potassium permanganate $(0.02 \mathrm{M})$ and sodium thiosulphate $(0.2 \mathrm{M})$ solutions were standardized before used.

\section{Viscosity}

Prior to viscosity determination, the pulp that was delignified as unbleach pulp was used. This was done to remove lignins and prevent clogging of capillary viscometer. Holocellulosic delignification process was based on the procedure developed by Browning [19], with some modifications. Oven dried (o.d.) pulp (2.5g) was mixed with required buffer solution in a $250 \mathrm{ml}$ elenmeyer flask, so that the combined pulp and solution weight equals to $83 \mathrm{~g}$. 
Viscosity determinations involved the technique of pulp dissolution and measurement of the resulting solution. The experiment was conducted according to TAPPI T230 om-89 [20] and the method used was mixing pulp and liquid in an open tube with a copper rod.

\section{Total yield determination}

\section{Results and Discussion}

Total yield is the percentage o.d. pulp weight compared to the o.d. EFB used during pulping. Total yield comprised of reject material, including uncooked EFB or undissolved substances in pulping liquor. Rejects will be collected on top of the screen plate with slots measuring $0.15 \mathrm{~mm}$. Pulp that could not pass through the screen plate were considered coarse and unsuitable for paper making. Rejected yield is the percentages of o.d. reject compared to the o.d. EFB weight before pulping. With reference to Table 2, it can be seen that the screened yield and reject yield is not equivalent to the total yield. There were areas of potential losses during washing, container transfer and pulp lodged at screen slots.

Table 2. Percentage of the pulping yield

\begin{tabular}{lc}
\hline Pulping Yield & Percentage (\%)* \\
\hline Total yield & 52.47 \\
Screened yield & 44.41 \\
Reject yield & 2.96 \\
Loss yield & 5.10 \\
\hline
\end{tabular}

*Average of 20 pulping batches

Table 3 shows the total yield, screened yield, Kappa number and viscosity responses. Total yield ranges from $35.70 \%$ to $58.87 \%$. These have given initial indication on how the total yield is dependent on the pulping procedures. For Experiment 6, the total yield is the lowest as two pulping factors namely temperature and alkali percent dosage were at the maximum value. High temperature and high alkali content caused more pulp degradation which lead to lower yield.

Table 3. Total yield, screened yield, Kappa number and viscosity responses

\begin{tabular}{|c|c|c|c|c|c|c|c|c|c|c|}
\hline \multirow{3}{*}{$\begin{array}{l}\text { No. of } \\
\text { Exp }\end{array}$} & \multicolumn{6}{|c|}{ Pulping Factors Combination } & \multirow{3}{*}{$\begin{array}{c}\text { Total } \\
\text { Yield, \% }\end{array}$} & \multirow{3}{*}{$\begin{array}{l}\text { Screened } \\
\text { Yield, \% }\end{array}$} & \multirow{3}{*}{$\begin{array}{c}\text { Kappa } \\
\text { Number }\end{array}$} & \multirow{3}{*}{$\begin{array}{c}\text { Viscosity } \\
\text { cP }\end{array}$} \\
\hline & \multicolumn{3}{|c|}{ Code } & \multicolumn{3}{|c|}{ Actual Value } & & & & \\
\hline & $\mathbf{T}$ & $\mathbf{t}$ & $\mathbf{A}$ & $\begin{array}{l}\mathbf{T}, \\
{ }^{\mathbf{0}} \mathbf{C}\end{array}$ & $\begin{array}{c}\mathbf{t}, \\
\text { min }\end{array}$ & $\begin{array}{l}\text { A, } \\
\%\end{array}$ & & & & \\
\hline 1 & -1 & -1 & -1 & 160 & 60 & 20 & 58.83 & 37.44 & 14.9 & 15.34 \\
\hline 2 & +1 & -1 & -1 & 180 & 60 & 20 & 56.88 & 44.70 & 10.8 & 10.47 \\
\hline 3 & -1 & +1 & -1 & 160 & 120 & 20 & 50.62 & 42.34 & 13.5 & 15.48 \\
\hline 4 & +1 & +1 & -1 & 180 & 120 & 20 & 53.09 & 49.99 & 9.6 & 9.13 \\
\hline 5 & -1 & -1 & +1 & 160 & 60 & 30 & 57.23 & 56.07 & 7.3 & 9.30 \\
\hline 6 & +1 & -1 & +1 & 180 & 60 & 30 & 35.70 & 34.57 & 7.7 & 9.19 \\
\hline 7 & -1 & +1 & +1 & 160 & 120 & 30 & 52.94 & 42.83 & 7.5 & 9.24 \\
\hline 8 & +1 & +1 & +1 & 180 & 120 & 30 & 39.17 & 37.73 & 5.8 & 5.43 \\
\hline 9 & -1.682 & 0 & 0 & 153 & 90 & 25 & 55.43 & 51.00 & 9.4 & 10.74 \\
\hline 10 & +1.682 & 0 & 0 & 187 & 90 & 25 & 55.91 & 42.09 & 7.9 & 7.11 \\
\hline
\end{tabular}



$\begin{array}{ll}\text { Nurul Husna et al: } & \text { RESPONSE SURFACE METHODOLOGY ON THE EFFECTS OF SODA - } \\ & \text { ANTHRAQUINONE PULPING CONDITIONS ON OIL PALM EMPTY FRUIT BUNCHES } \\ & \text { PULP PROPERTIES }\end{array}$

Table 3 (cont'd). Total yield, screened yield, Kappa number and viscosity responses

\begin{tabular}{|c|c|c|c|c|c|c|c|c|c|c|}
\hline \multirow{3}{*}{$\begin{array}{l}\text { No. of } \\
\text { Exp }\end{array}$} & \multicolumn{6}{|c|}{ Pulping Factors Combination } & \multirow{3}{*}{$\begin{array}{c}\text { Total } \\
\text { Yield, \% }\end{array}$} & \multirow{3}{*}{$\begin{array}{l}\text { Screened } \\
\text { Yield, \% }\end{array}$} & \multirow{3}{*}{$\begin{array}{c}\text { Kappa } \\
\text { Number }\end{array}$} & \multirow{3}{*}{$\begin{array}{c}\text { Viscosity } \\
\text { cP }\end{array}$} \\
\hline & \multicolumn{3}{|c|}{ Code } & \multicolumn{3}{|c|}{ Actual Value } & & & & \\
\hline & $T$ & $\mathbf{t}$ & $\mathbf{A}$ & $\begin{array}{l}\mathrm{T}, \\
{ }^{\circ} \mathrm{C}\end{array}$ & $\begin{array}{c}\mathbf{t}, \\
\min \end{array}$ & $\begin{array}{l}\mathrm{A}, \\
\%\end{array}$ & & & & \\
\hline 11 & 0 & -1.682 & 0 & 170 & 40 & 25 & 58.87 & 40.98 & 12.4 & 16.02 \\
\hline 12 & 0 & +1.682 & 0 & 170 & 141 & 25 & 49.88 & 48.77 & 7.2 & 7.95 \\
\hline 13 & 0 & 0 & -1.682 & 170 & 90 & 16.6 & 58.82 & 30.37 & 15.6 & 14.34 \\
\hline 14 & 0 & 0 & +1.682 & 170 & 90 & 33.4 & 53.44 & 37.17 & 6.7 & 7.90 \\
\hline 15 & 0 & 0 & 0 & 170 & 90 & 25 & 52.27 & 47.94 & 9.1 & 7.67 \\
\hline 16 & 0 & 0 & 0 & 170 & 90 & 25 & 51.06 & 49.62 & 8.7 & 9.02 \\
\hline 17 & 0 & 0 & 0 & 170 & 90 & 25 & 53.80 & 50.52 & 7.9 & 8.51 \\
\hline 18 & 0 & 0 & 0 & 170 & 90 & 25 & 56.37 & 49.20 & 8.1 & 9.74 \\
\hline 19 & 0 & 0 & 0 & 170 & 90 & 25 & 50.02 & 49.13 & 8.4 & 8.73 \\
\hline 20 & 0 & 0 & 0 & 170 & 90 & 25 & 48.99 & 45.65 & 9.4 & 9.80 \\
\hline
\end{tabular}

Total yield ANOVA analysis

Exprimental data obtained was statisticaly analysed by RSM to ascertain the suitable model selection for each surface response. Analysis of variance (ANOVA) evaluation included Sequential Model Sum of Squares (SMSS), Lack of Fit (LOF) and Model Summary Statistic (MSS) [21].

Through RSM, the linear and quadratic models are the most probably suitable models. The models were chosen based on the Probability of a larger F (Prob. F.), which in SMSS is significant with Prob. F $<0.05$ and not significant in LOF with Prob. F > 0.10. In MSS, a model was chosen based on the minimum Predicted Residual Sum of Squares, (PRESS) and maximum Multiple Correlation Coefficient, $\mathrm{R}^{2}$.

Table 4 shows the ANOVA analysis for total yield. From SMSS total yield, F-value for quadratic model is highly significant at 0.0091 compared to 0.0361 for the linear model. LOF Prob. F value for quadratic model shows insignificant value (0.1129) as opposed to linear model (0.0499). Based on MSS, the most suitable model is quadratic, with higher $\mathrm{R}^{2}$ of 0.6861 as compared to -0.0650 for linear model. The correlation between the quadratic model and soda-AQ pulping conditions showed that the total yield increased with the increasing of the pulping conditions. However, at a certain stage of pulping conditions, the total yield can be decreased due to high severity in pulping conditions especially at high temperature and high alkali percentage. Quadratic regression model for total yield is represented by equation 4 for the surface response for total yield.

Table 4. Total yield ANOVA analysis

\begin{tabular}{|c|c|c|c|c|}
\hline $\begin{array}{l}\text { Pulping } \\
\text { Yield }\end{array}$ & Model & $\begin{array}{l}\text { Sequential Model } \\
\text { Sum of Squares } \\
\text { (SMSS)* }\end{array}$ & $\begin{array}{l}\text { Lack of Fit Test } \\
(\text { LOF })^{\#}\end{array}$ & $\begin{array}{l}\text { Model Summary Statistic } \\
\text { (MSS) }\end{array}$ \\
\hline \multirow{2}{*}{$\begin{array}{l}\text { Total Yield, } \\
\%\end{array}$} & Linear & $\begin{array}{l}\text { F-value }=3.63 \\
\text { Prob. } F=0.0361\end{array}$ & $\begin{array}{l}\text { F-value }=4.71 \\
\text { Prob. } F=0.0499\end{array}$ & $\begin{array}{l}\mathrm{R}^{2}=-0.0650 \\
\mathrm{PRESS}=736.27\end{array}$ \\
\hline & Quadratic & $\begin{array}{l}\text { F-value }=4.74 \\
\text { Prob. } F=0.0091\end{array}$ & $\begin{array}{l}\text { F-value }=3.12 \\
\text { Prob. } F=0.1129\end{array}$ & $\begin{array}{l}\mathrm{R}^{2}=0.6861 \\
\mathrm{PRESS}=793.31\end{array}$ \\
\hline
\end{tabular}


Total yield, $\%=-165.19+1.53 \mathbf{T}-1.16 \mathbf{t}+13.75 \times 10^{-3} \mathbf{T t}-0.09 \mathbf{T A}+9.317 \times 10^{-3} \mathbf{t A}$

\section{Effect of pulping conditions on total yield}

Effect of pulping conditions on total yield could not be clearly seen if the analysis is done only through ANOVA and best-fit-model. To explain a model easier, a three dimensional (3D) graph plot was used. However, the 3D plot could only show the effect of two factors and one response at a time. Therefore, one of the factors must be kept constant. Through pertubation plot, factors that have the highest effect on a response were represented by $\mathrm{X}$ and $\mathrm{Y}$ axis while the $\mathrm{Z}$ axis represented the lowest effect response of pulping factors.

Figure 1 shows the pertubation plot for total yield. Temperature and alkali factors showed more impact on total yield compared to time factor and will be represented by the $\mathrm{X}$ and $\mathrm{Y}$ axis. Figure 2 shows the $3 \mathrm{D}$ plot for total yield of alkali and temperature at 60 min time. Total yield decreased when time increased to $90 \mathrm{~min}$ and $120 \mathrm{~min}$. This was expected as more lignin, hemicellulose and cellulose were dissolved with the increase of pulping time.

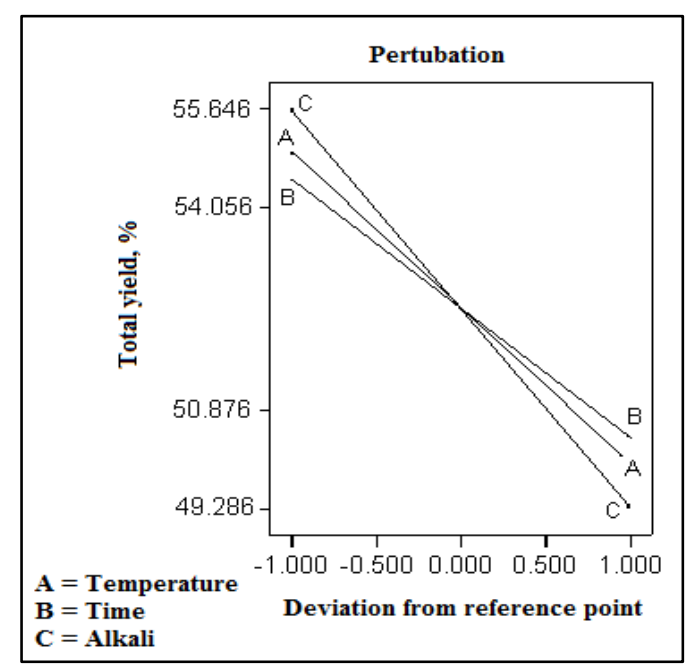

Figure 1. Total yield perturbation plot

According to Smook [22], if pulping was done at range of $155-175^{\circ} \mathrm{C}$, the delignification rate will be doubled for every $10^{\circ} \mathrm{C}$ increment. Since the temperature used in this study was $160-180^{\circ} \mathrm{C}$, it was not a surprise if the total yield decreased with the increase of temperature. Pulping at high temperature encouraged dissolution of lignin and carbohydrate. This finding is supported by Mimms et al. [23] where small increment in temperature was shown to have large effect on delignification rate. When temperature above $175^{\circ} \mathrm{C}$ was used, lignin selection became lower and more cellulose degredation occurred, causing lower yield. High temperature would cause more degradation of hemicellulose and cellulose. Thus, total yield decreased as temperature increased.

Increasing alkali contents also decreases total yield. Soda easily interacts with the phenolic functionality of the lignins by rendering it to be soluble in aqueous solution. Subsequently, delignification rate increases with increasing of alkali percentage. The amount of dissolved hemicellulose will also increase as the amorphous structure opens and the hydroxyl functionality reacts leading to yield reduction. Hydroxyl ion $\left(\mathrm{OH}^{-}\right)$is an active component in pulping.Hydroxyl ions concentration plays a major role during pulping for lignin solubilization and unwanted reaction such as cellulose degradation [24].

Temperature and alkali factors have interactions that affect the total yield. With reference to Figure 2, total yield only increased at either high alkali dosage with low temperature, or at high temperature with low alkali dosage. 


\section{Nurul Husna et al: RESPONSE SURFACE METHODOLOGY ON THE EFFECTS OF SODA - ANTHRAQUINONE PULPING CONDITIONS ON OIL PALM EMPTY FRUIT BUNCHES PULP PROPERTIES}

High alkali dosage and high temperature combination caused yield reduction. Degradation of cellulose, hemicellulose and lignin desolubilization is high in these conditions.

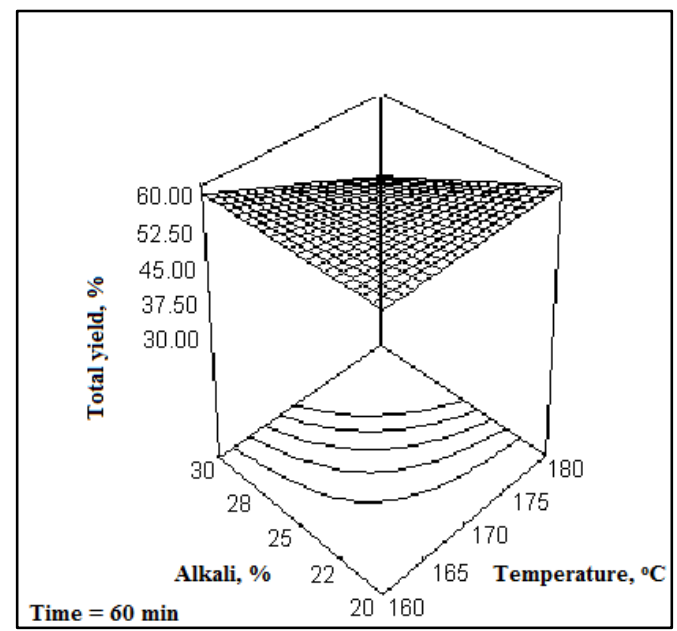

Figure 2. 3D plot on effect of alkali $(A)$ and temperature $(T)$ on total yield variation at time $(\mathrm{t})=60$ minutes

In conclusion, temperature and alkali factors give stronger effects toward total yield, compared to time factor. To obtain high total yield, level of temperature, alkali and time has to be used at the lower value. However, it should be noted that, total yield still includes rejects from coarse undissolved EFB during pulping which adds on to total yield weight during yield determination process.

\section{Screened yield determination}

Screened yield was obtained after the total yield pulp had undergone screening process and pulp had passed the screen slot plates routed to astrainer. Screened yield percentage is the screened pulp o.d. weight over the o.d. weight of EFB used. Based on Table 3, the screened yield ranged between $30.37 \%$ and $56.07 \%$ experiment 5 showed the highest percentage of screened yield. It is believed that the pulping factors were at optimum level, namely low temperature with short time and high alkali dosage. This was proven by optimum factors level suggested by RSM during optimization process in which the pulping factors were at $160{ }^{\circ} \mathrm{C}$ temperature, 60 minutes time and $27.3 \%$ of alkali percentage.

\section{Screened yield ANOVA analysis}

ANOVA of screened yield (Table 5) showed SMSS quadratic model with highly significant F-value 0.0007 compared to linear model with insignificant $\mathrm{F}$-value 0.6888 . Both models are significant for LOF but quadratic model has higher insignificant value at 0.0369 , compared to linear model at 0.0014 . Observation of MSS strengthens the choice of quadratic model with high $\mathrm{R}^{2}$ and low PRESS of 0.1194 and 719.28 as compared to 0.5783 and 1289.18 for linear model respectively. Equation 5 gives the response surface representing quadratic model for screened yield. 
Table 5. Screened yield ANOVA analysis

\begin{tabular}{lllll}
\hline $\begin{array}{l}\text { Pulping } \\
\text { Yield }\end{array}$ & Model & $\begin{array}{l}\text { Sequential Model Sum of } \\
\text { Squares (SMSS)* }\end{array}$ & $\begin{array}{l}\text { Lack of Fit Test } \\
(\text { LOF) }\end{array}$ & $\begin{array}{l}\text { Model Summary } \\
\text { Statistic (MSS) } ;\end{array}$ \\
\hline \multirow{3}{*}{$\begin{array}{l}\text { Screened } \\
\text { yield, \% }\end{array}$} & Linear & $\begin{array}{l}\text { F-value }=0.05 \\
\text { Prob. } F=0.6888\end{array}$ & $\begin{array}{l}\text { F-value }=23.01 \\
\text { Prob. F }=0.0014\end{array}$ & $\begin{array}{l}\mathrm{R}^{2}=-0.5783 \\
\text { PRESS }=1289.18\end{array}$ \\
\cline { 2 - 5 } & Quadratic & $\begin{array}{l}\text { F-value }=10.80 \\
\text { Prob. } F=0.0007\end{array}$ & $\begin{array}{l}\text { F-value }=5.90 \\
\text { Prob. F }=0.0369\end{array}$ & $\begin{array}{l}\mathrm{R}^{2}=0.1194 \\
\text { PRESS }=719.28\end{array}$ \\
\hline
\end{tabular}

* Choose model with significant Prob. F (Prob. F $<0.05$ ).

\# Choose model with insignificant Prob. F (Prob. F >0.10).

$\$$ Choose model with high $\mathrm{R}^{2}$ and low PRESS values.

Screened yield, $\%=-528.223+2.97 \mathbf{T}-0.55 \mathbf{t}+29.02 \mathbf{A}-3.527 \times 10^{-3} \mathbf{T}^{2}-1.048 \times 10^{-3} \mathbf{t}^{2}-0.19 \mathbf{A}^{2}+6.996 \times 10^{-3} \mathbf{T t}-$ $0.10 \mathbf{T A}-0.017 \mathrm{tA}$

\section{Effect of pulping conditions on screened yield}

Screened yield perturbation plot is shown in Figure 3. From all the three factors tested, temperature and alkali factors gave higher impact on the screen yield compared to time. Thus, the $\mathrm{X}$-axis represents temperature and $\mathrm{Y}$ axis represents alkali.

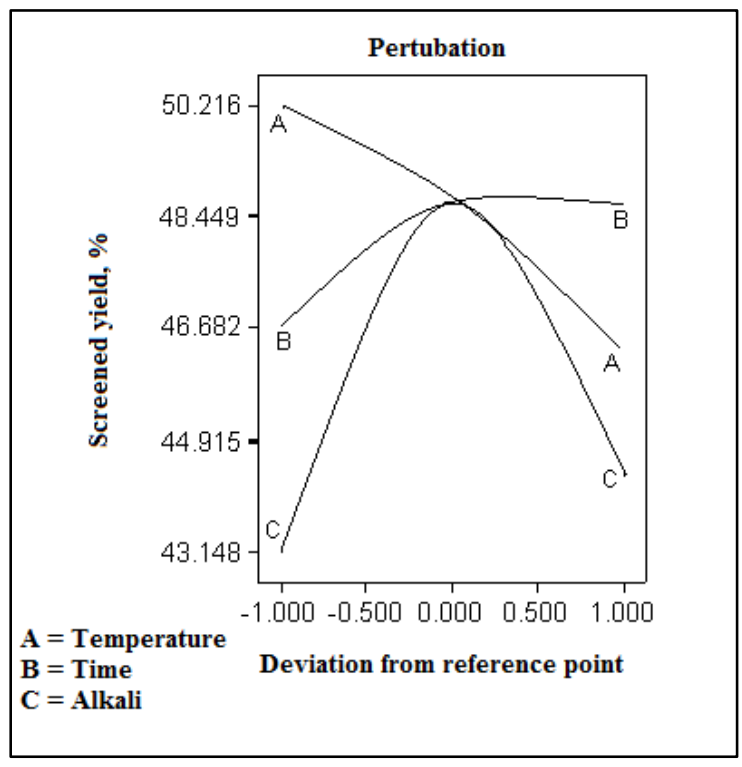

Figure 3. Screened yield perturbation plot

Figure 4 shows the 3D illustration of screened yield affected by temperature and alkali factors. Time factor was kept constant at 60 minutes as it has less impact on screened yield. However, the effect of time can be seen on screened yield when quadratic model on the surface response of Figure 4 shows changes in screened yield reduction as time increases. This is due to the cellulose degradation which occurs at longer pulping time.

As the alkali percentage increased, screened yield also increased as more lignin can be dissolved. This is similarly reported by Khairunisak et al. [24] where as active alkali increased, pulping yield increased. On the other hand, if alkali percentage is too low, incomplete EFB pulping process will produced high rejects yield and thus decreased 


\section{Nurul Husna et al: RESPONSE SURFACE METHODOLOGY ON THE EFFECTS OF SODA - ANTHRAQUINONE PULPING CONDITIONS ON OIL PALM EMPTY FRUIT BUNCHES PULP PROPERTIES}

the screened yield. The same could be said for temperature factor. Screened yield increased with the increasing in temperature as at range of $150-170{ }^{\circ} \mathrm{C}$, and at lower temperature delignification was incomplete [23]. At higher temperature, more lignin could be dissolved at faster rate.

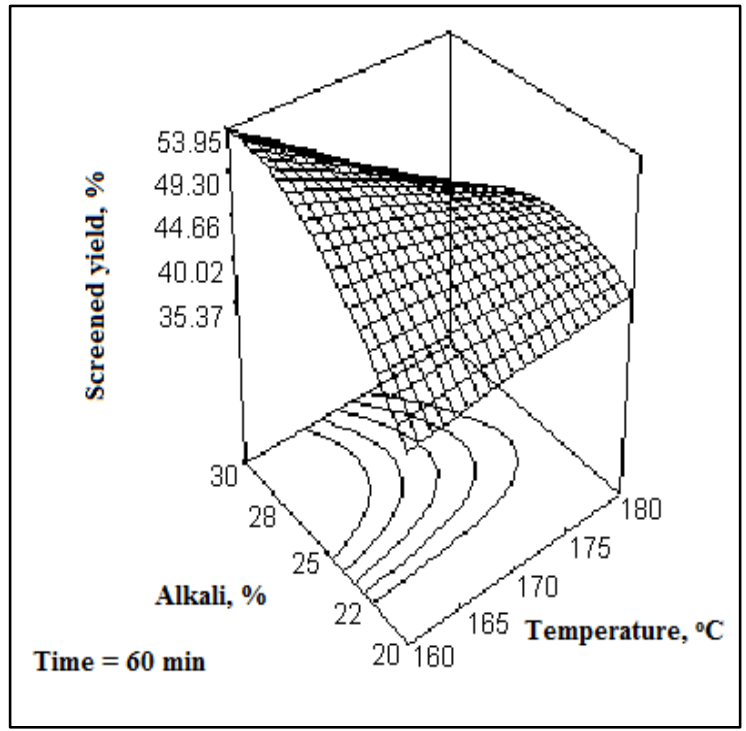

Figure 4. 3D plot on effect of alkali (A) and temperature $(T)$ on screened yield variation at time $(t)=60$ minutes

Alkali concentration has stronger impact on lignin dissolution compared to both temperature and time. The alkali impact become more important as temperature increased [25]. The combination of these factors has resulted in more efficient pulping digestion.There is an interaction between temperature and alkali factor which resulted in screened yield quantum. With reference to Figure 4, increase in screened yield with respect to temperature increase will only occur at low alkali percentage $(<25 \%)$. This is because, at low alkali percentage, high pulping temperature can increase delignification rate resulting in higher screened yield. When alkali percentage is at high level $(>25 \%)$, rising pulping temperature will cause screened yield reduction as some of the carbohydrate also dissolved instead of just lignin.

Thus, it could not be denied that the used of too high alkali percentage and high temperature, would cause fibres to undergo severe degradation and produced lower yield. The effect intensifies with longer time used. These conditions could be seen in Figure 4 as the screened yield dropped when the pulping time was increased. At this point, the cellulose and hemicellulose undergo degradation causing formation of fines which flushed through the screening wire mesh, leading to screened yield reduction.

\section{Kappa number}

Kappa number is defined as volume $(\mathrm{ml})$ of $0.1 \mathrm{~N}$ aqueous potassium permanganate used by $1 \mathrm{~g}$ of o.d. pulp under specified conditions. This is an indirect method to identify the lignin content via oxidation of lignin through reaction with aqueous potassium permanganate. Kappa number has a relationship to lignin for pulp with yield lower than $70 \%$. Percentage of lignin is estimated and factored at $\mathrm{K} \mathrm{x} 0.15$ [22].Within the industry, Kappa number test is used to check the degree of delignification during pulping and to determine chemical requirement for bleaching.Table 3 shows the Kappa number at various pulping conditions. Kappa number ranges from 5.8 to 15.6. This values neccessitate bleaching process to be done, if the pulp is needed for dissolving pulp experiments.

\section{Kappa number ANOVA Analysis}

Table 6 shows the ANOVA on resultant Kappa number. With reference to SMSS, both linear and quadratic model are significant with Prob $F<0.0001$. At LOF, only quadratic model shows insignificant value of 0.1229 . MSS 
observations strengthen the choice of quadratic model due to higher $\mathrm{R}^{2}$ and lower PRESS $(0.9446$ and 42.28 respectively) compared to linear model ( 0.6944 and 42.87 respectively). Equation 6 represents surface acceptance for Kappa number quadratic model.

Table 6. Kappa number ANOVA Analysis.

\begin{tabular}{lllll}
\hline $\begin{array}{l}\text { Pulp } \\
\text { Properties }\end{array}$ & Model & $\begin{array}{l}\text { Sequential Model Sum } \\
\text { of Squares (SMSS)* }\end{array}$ & $\begin{array}{l}\text { Lack of Fit Test } \\
(\text { LOF) }\end{array}$ & $\begin{array}{l}\text { Model Summary } \\
\text { Statistic (MSS) }\end{array}$ \\
\hline \multirow{3}{*}{ Kappa number } & Linear & $\begin{array}{l}\text { F-value }=24.05 \\
\text { Prob. } F<0.0001\end{array}$ & $\begin{array}{l}\text { F-value }=6.43 \\
\text { Prob. } F=0.0261\end{array}$ & $\begin{array}{l}\mathrm{R}^{2}=0.6944 \\
\text { PRESS }=42.87\end{array}$ \\
\cline { 2 - 5 } & Quadratic & $\begin{array}{l}\text { F-value }=23.46 \\
\text { Prob. } F<0.0001\end{array}$ & $\begin{array}{l}\text { F-value }=3.20 \\
\text { Prob. } F=0.1229\end{array}$ & $\begin{array}{l}\mathrm{R}^{2}=0.9446 \\
\text { PRESS }=42.28\end{array}$ \\
\hline
\end{tabular}

* Choose model with significant Prob. F (Prob. F $<0.05$ ).

\# Choose model with insignificant Prob. F (Prob. F >0.10).

$\$$ Choose model with high $\mathrm{R}^{2}$ and low PRESS values.

Kappa Number $=+124.22-0.43 \mathbf{T}+0.011 \mathbf{t}-5.12 \mathbf{A}+4.04 \times 10^{-4} \mathbf{t}^{2}+0.034 \mathbf{A}^{2}-7.917 \times 10^{-4} \mathbf{T t}+0.017 \mathbf{T A}+$ $7.5 \times 10^{-4} \mathbf{t A}$

\section{Effect of pulping conditions on Kappa number}

Figure 5 shows the pertubation plot for Kappa number. The alkali factor gives the highest effect on Kappa number compared to other pulping factors. Percentage difference of alkali at constant temperature and pulping time will yield significant Kappa number change.

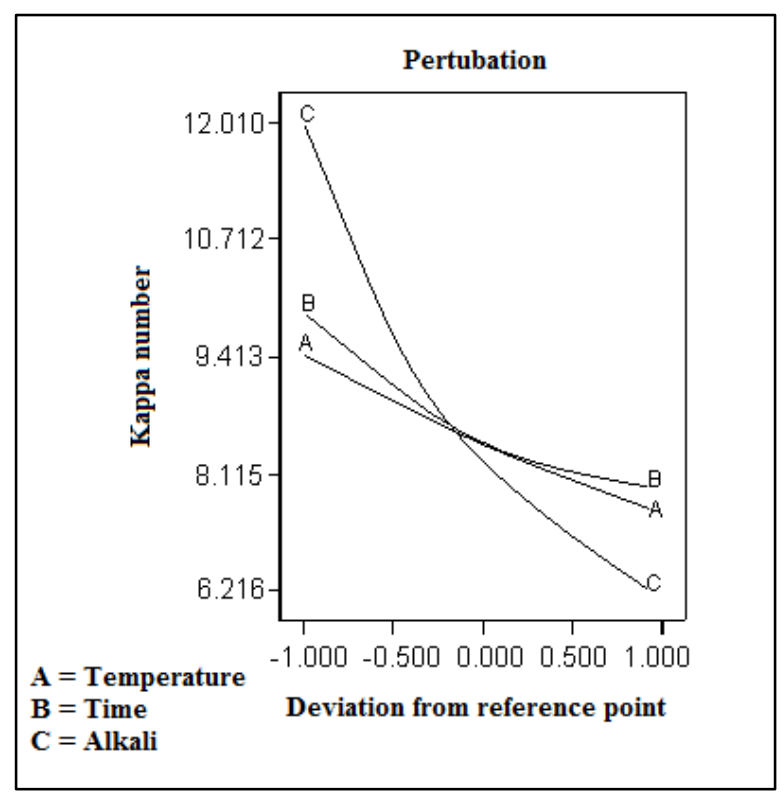

Figure 5. Kappa number perturbation plot

Examples of observation; Experiment 13 which used the lowest alkali percentage (16.6\%) and Experiment 14 which used the highest alkali percentage (33.4\%) were done at same pulping temperature and time. Experiment 13 gave high Kappa number reading while Experiment 14 gave low Kappa number reading.The Kappa number was 


\section{Nurul Husna et al: RESPONSE SURFACE METHODOLOGY ON THE EFFECTS OF SODA - ANTHRAQUINONE PULPING CONDITIONS ON OIL PALM EMPTY FRUIT BUNCHES PULP PROPERTIES}

determined through observation of reaction of potassium permanganate with any lignin presence in pulp. Difference in effects of alkali factor can be directly seen by the colour variation in resultant pulp.

$\mathrm{X}$-axis represents temperature and $\mathrm{Y}$-axis represents alkali percentage. When temperature increase, the Kappa number will decrease as lignin dissolves faster at higher temperature. Kappa number value is closely linked to lignin content in pulp. High Kappa number shows high lignin content in pulp while low Kappa number shows low lignin content [26].

When alkali percentage increased, Kappa number decreased. This happened as more lignin dissolved and only small amount of lignin is still left in the pulp. High alkali percentage will dissolve more lignin component and decrease the Kappa number. Figure 6 shows the effects of Kappa number with alkali and temperature at constant time. Lengthening of time will remove more lignin and thus reduced Kappa number. According to Kleppe [27] high lignin content in pulp will control strength quality and optical quality of paper. High lignin content in paper will reduce paper strength and optical characteristic. Thus, the function of pulping is to maximize the removal of lignin into the pulping liquor.

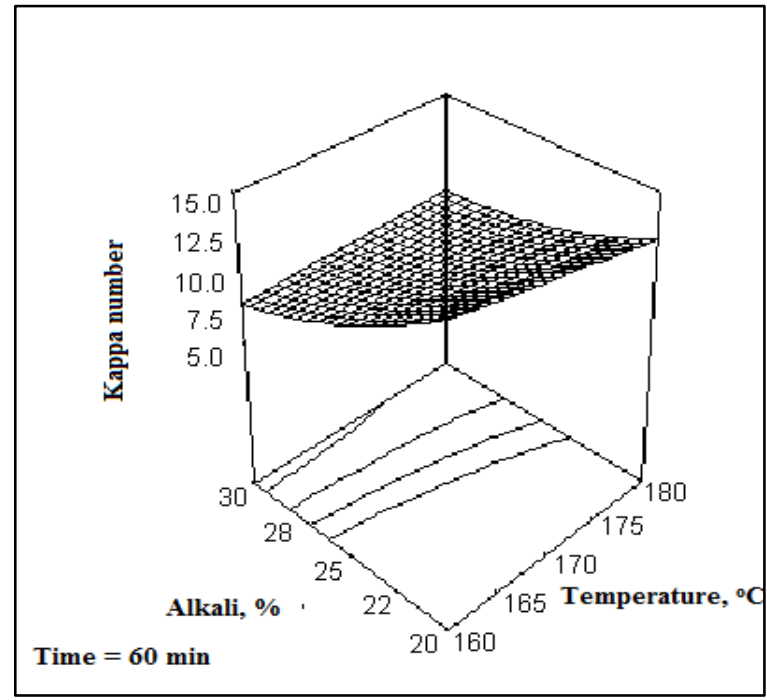

Figure 6. 3D plot on effect of alkali (A) and temperature (T) on Kappa number variation at time $(t)=60$ minutes

\section{Viscosity}

Viscosity of a pulp solution indicates the average degree of cellulose polymerization. This test gives a relative indication on the reduction of cellulose molecule weight caused by the pulping process. Among the methods used to confirm the average cellulose degree of polymerization (dp) is by measuring the cellulose solution viscosity with known concentration in solvent such as cupriethylene diamine (CED), as CED can dissolve cellulose faster and has good chemical stability [22]. Table 3 shows the viscosity response which varies according to the pulping treament. Viscosity obtained ranges from $5.43-16.06 \mathrm{cP}$.

\section{Viscosity ANOVA analysis}

Table 7 shows the ANOVA analysis for viscosity response with quadratic model. F probability value at SMSS clearly shows the appropriate choice of quadratic model even though both linear and quadratic model give significant SMSS. Quadratic model was chosen as it has lower value that of $p<0.0001$. However, observation at LOF shows insignificant value for quadratic model than linear model at 0.1061 and 0.0261 respectively. With reference to MSS, the choice of using quadratic model is stronger as it has high $\mathrm{R}^{2}$ and lower PRESS compared to linear model. Equation 7 describes the surface response plot for reducing quadratic model for viscosity. 
Table 7. Viscosity ANOVA analysis

\begin{tabular}{llcll}
\hline $\begin{array}{l}\text { Pulp } \\
\text { Properties }\end{array}$ & Model & $\begin{array}{l}\text { Sequential Model Sum } \\
\text { of Squares (SMSS)* }\end{array}$ & $\begin{array}{l}\text { Lack of Fit Test } \\
(\text { LOF) }\end{array}$ & $\begin{array}{l}\text { Model Summary } \\
\text { Statistic (MSS) } \$\end{array}$ \\
\hline \multirow{3}{*}{ Viscosity, cP } & Linear & $\begin{array}{l}\text { F-value }=12.70 \\
\text { Prob. F }=0.0002\end{array}$ & $\begin{array}{l}\text { F-value }=6.44 \\
\text { Prob. F }=0.0261\end{array}$ & $\begin{array}{l}\mathrm{R}^{2}=0.5042 \\
\text { PRESS }=81.76\end{array}$ \\
\cline { 2 - 5 } & Quadratic & $\begin{array}{l}\text { F-value }=14.10 \\
\text { Prob. F }<0.0001\end{array}$ & $\begin{array}{l}\text { F-value }=3.26 \\
\text { Prob. F }=0.1061\end{array}$ & $\begin{array}{l}\mathrm{R}^{2}=0.8916 \\
\text { PRESS }=76.74\end{array}$ \\
\hline
\end{tabular}

* Choose model with significant Prob. F (Prob. F $<0.05)$.

\# Choose model with insignificant Prob. F (Prob. F $>0.10$ ).

$\$$ Choose model with high $\mathrm{R}^{2}$ and low PRESS values.

Viscosity, $\mathrm{cP}=+121.32-0.42 \mathbf{T}+0.21 \mathbf{t}-4.94 \mathbf{A}+1.136 \times 10^{-3} \mathbf{t}^{2}+0.029 \mathbf{A}^{2}-2.158 \times 10^{-3} \mathbf{T t}+0.018 \mathbf{T A}$

\section{Effect of pulping conditions on viscosity}

Figure 7 shows the perturbation plot for viscosity response. It can be seen that time and alkali percentage gave higher influence than temperature. Therefore, $\mathrm{X}$-axis represented time and $\mathrm{Y}$-axis represented alkali. In the meantime, the temperature was kept constant at $160^{\circ} \mathrm{C}$ as in Figure 8 . Temperature had minimal effect on viscosity as the response surface plot only moved slighty downwards as temperature was increased from $160{ }^{\circ} \mathrm{C}$ to $170{ }^{\circ} \mathrm{C}$ and from $170{ }^{\circ} \mathrm{C}$ to $180{ }^{\circ} \mathrm{C}$.

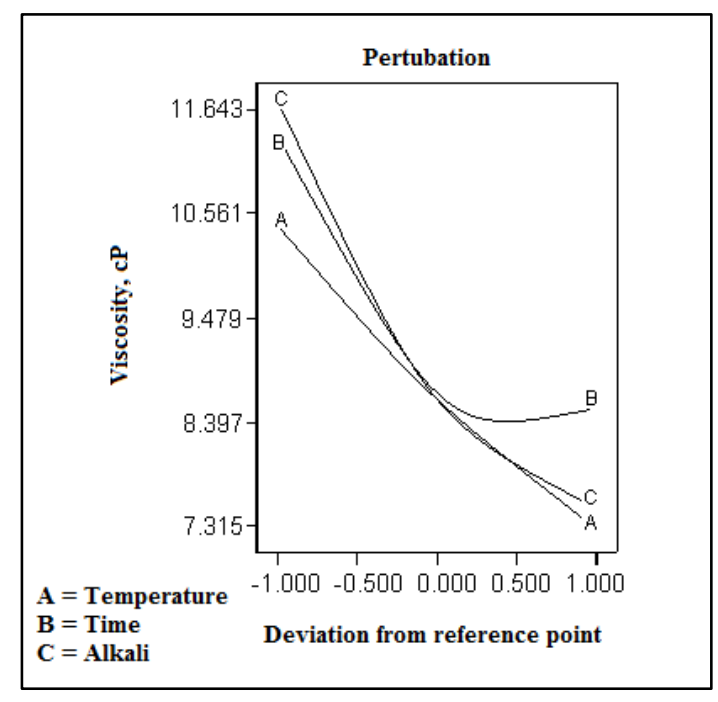

Figure 7. Viscosity pertubation plot

At long pulping duration, the viscosity value dropped at less than $11 \mathrm{cP}$. Similarly, when alkali percentages increased, viscosity decreased. Viscosity reduction was caused by the degradation of cellulose chain during pulping process especially at high temperature and high alkali percentage. Moreover, soda can act as a surface tension reduction agent which had lowered the viscosity as solution.

In conclusion, pulp sample that undergoes extreme severity during pulping process has low viscosity while pulp which undergoes less severity has high viscosity. This is due to longer cellulose chain having stronger internal interactions and being easily tangled thus becoming more viscous. As consequence, it will take longer time to pass through viscometer capillary tube. 
Nurul Husna et al: RESPONSE SURFACE METHODOLOGY ON THE EFFECTS OF SODA ANTHRAQUINONE PULPING CONDITIONS ON OIL PALM EMPTY FRUIT BUNCHES PULP PROPERTIES

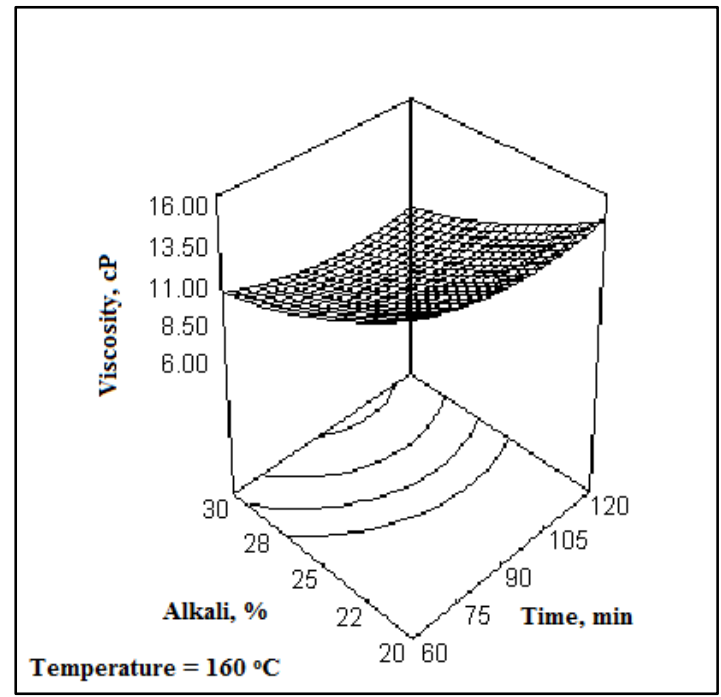

Figure 8. 3D plot on effect of alkali (A) and time (t) on viscosity variation at temperature $(\mathrm{T})=160{ }^{\circ} \mathrm{C}$

\section{Optimization of pulping parameters}

To get the desired pulp quality, the pulp criteria were set to a fixed value. A few pulping level factors were suggested by the Design-Expert software as listed in Table 8. An experiment was done by using the solution factors at solution number 1 to obtain the nearest values according to predicted values for pulp properties.

Table 8. Pulping factors level suggested by Design Expert software for optimum pulp properties

\begin{tabular}{|c|c|c|c|c|c|c|c|c|}
\hline \multirow{2}{*}{ Solution } & \multicolumn{3}{|c|}{ Pulping Parameters } & \multicolumn{5}{|c|}{ Pulp Properties } \\
\hline & $\mathrm{T},{ }^{\circ} \mathrm{C}$ & $t, \min$ & $\mathrm{A}, \%$ & $T Y$ & $S Y$ & $K N$ & $V$ & Achievability \\
\hline 1 & 160.00 & 60.00 & 27.30 & 55.53 & 53.20 & 9.85 & 12.02 & 0.713 \\
\hline 2 & 160.21 & 60.10 & 27.28 & 55.48 & 53.06 & 9.83 & 11.99 & 0.711 \\
\hline
\end{tabular}

$T Y=$ total yield, $S Y=$ screened yield, $K N=$ Kappa number, $V=$ viscosity

\section{Conclusion}

With reference to RSM usage, it can be concluded that alkali and temperature factors give the highest influence to most of pulp properties (total yield, screened yield and Kappa number). The combination of alkali and time factors gives more influence to viscosity response. The research objective to investigate the effects of pulping factors on pulp properties on total yield, screened yield, Kappa number and viscosity, was achieved. Total yield decreases with the increase of temperature, time and alkali. Screened yield increases with the increase of pulping factors up to $58.83 \%$ and then drops to $35.70 \%$ with extreme pulping condition usage. Kappa number and viscosity decrease with the increase of pulping factors. The optimum pulping conditions are temperature at $160{ }^{\circ} \mathrm{C}$, pulping time at 60 minutes and alkali percentage at $27.3 \%$. This is achievable at $71 \%$ to obtain $55.53 \%$ of total yield, $53.20 \%$ of screened yield, 9.85 of Kappa number and $12.02 \mathrm{cP}$ of pulp viscosity.

\section{Acknowledgement}

The authors would like to express their appreciation to SABUTEK Sdn. Bhd., Teluk Intan, Perak, for providing the raw material for this study. 


\section{References}

1. Khozirah, S. and Khoo, K. C. (1991). Oil palm utilisation-review of research, Forest Research Institute (FRIM), Kepong, Selangor. Research Pamphlet No.107: 1-7

2. Moll, H. A. J. (1987). The economics of oil palm. economics of crops in developing Countries No.2. Pudoc Wageningen, Netherlands.

3. Sulaiman, O., Salim, N., Nordin, N.A., Hashim, R., Ibrahim, M. and Sato, M. (2012). The potential of oil palm trunk biomass as an alternative source for compressed wood. BioResearch, 7(2):688-706.

4. Jalani, B. S. (2002). Prospects of elevating national oil palm productivity: A Malaysian perspective. Oil Palm Industry Economic Journal, 2: 1-9.

5. Abdullah, R. (2003). Short-term and long-term projection of Malaysian palm oil production. Oil Palm Industry Economic Journal, 3:32-36.

6. MPOB (2015). Economic \& industry development devision. oil palm planted area. Retrieved from: http://bepi.mpob.gov.my/index.php/statistics/area.html.

7. Mohd-Fahmi, A., Othman, S., Rokiah, H. and Wan Noor Aidawati, W. N. (2015). An overview of the oil palm industry in Malaysia and its waste utilization through thermochemical conversion specifically via liquefaction. Renewable and Sustainable Energy Reviews, 50:1469-1484.

8. Shafie, S., Mahlia, T., Masjuki, H. and Andriyana, A. (2011). Current energy usage and sustainable energy in Malaysia: A review. Renewable and Sustainable Energy Reviews, 15(9): 4370-4377.

9. Wan Rosli, W. D., Leh, C. P., Zainuddin, Z. and Tanaka, R. (2003). Optimisation of soda pulping variables for preparation of dissolving pulps from oil palm fibre, Holzforschung, Walter de Gruyter, 57 (1), 106-113.

10. MPOPC (2004). Malaysian palm oil promotion council, Kuala Lumpur, Malaysia. Retrieved from:http://www.mpopc.org.my.

11. AIM (2013). National biomass strategy (2020): New wealth creation for Malaysia's biomass industry: Version 2.0, 2013. Agensi Inovasi Malaysia, Kuala Lumpur.

12. Amiruddin, M. N., Abrahman, A. K. and Shariff, F. (2005). Market potential and challenges for the Malaysian palm oil industry in facing competition from other vegetable oils. Oil Palm Industry Economic Journal, 5: $17-27$.

13. FAOSTAT (2015). Food and Agriculture Organization of the United Nations for a world without hunger. Retrieved from: $h$ ttp://faostat.fao.org/site/339/default. aspx.=

14. Faizi, M. K., Shahriman, A.B, Abdul Majid, M. S., Shamsul, B. M. T., Ng, Y. G., Basah, S. N., Cheng, E. M., Afendi, M., Zuradzman, M. R., Khairunizam, W. A. N. and Hazry, D. (2017). An overview of the oil palm empty fruit bunch (OPEFB) potential as reinforcing fibre in polymer composite for energy absorption applications MATEC Web of Conferences 90: 01064.

15. Eckert, R. C., Pfeiffer, G. O., Gupta, M. K. and Lower, C. R. (1984). Soda anthraquinone pulping of Douglas fir. TAPPI: Journal of the Technical Association of the Pulp and Paper Industry, 67(11): 104-108.

16. Hart, P. W and Rudie, A. W. (2014). Anthraquinone-A review of the rise and fall of a pulping catalyst. TAPPI: Journal of the Technical Association of the Pulp and Paper Industry, 13(10): 23-31.

17. TAPPI test methods 1994 - 1995 (1994). T211 Ash in wood, pulp, paper and paperboard: combustion at $525^{\circ} \mathrm{C}$. Vol. I, Atlanta, Georgia, Tappi Press.

18. TAPPI test methods 1994 - 1995 (1994). T236 Kappa Number of Pulp. Vol. I, Atlanta, Georgia, Tappi Press.

19. Browning, B. L. (1967). Methods of wood chemistry, Vol. II, Interscience Publishers, John Wiley \& Sons, Inc.

20. TAPPI test methods 1994 - 1995 (1994). T230 Viscosity of pulp (Capillary Viscometer Method). Vol. I, Atlanta, Georgia, Tappi Press.

21. Kraber, S. (1997). Handbook for experimenters, Minneapolis: Stat-Ease Inc.

22. Smook, G. A. (1992). Handbook for pulp \& paper technologist, $2^{\text {nd }}$ Edition, Vancouver, Angus Wilde Publications.

23. Mimms, A., Kocurek, M. J., Pyatte, J. A. and Wright, E. E. (1989). Kraft Pulping: A compilation of notes, United State of America: Atlanta, Tappi Press.

24. Khairunisak, A. R., Hong, O. B., Zakaria, S., Ahmad, S. and Mohd Yussof, M. N. (2002). Effect of Kraft pulping with anthraquinone and methanol on oil palm empty fruit bunches. Proceeding $5^{\text {th }}$ national seminar on utilization of oil palm tree - oil palm biomass: opportunities and challenges in commercial exploitation, Kuala Lumpur, oil palm tree utilization committee of Malaysia: pp. 205-210. 
Nurul Husna et al: RESPONSE SURFACE METHODOLOGY ON THE EFFECTS OF SODA ANTHRAQUINONE PULPING CONDITIONS ON OIL PALM EMPTY FRUIT BUNCHES PULP PROPERTIES

25. Iglesias, G., Bao, M., Lamas, J. and Vega, A. (1996). Soda pulping of Miscanthus sinensis. Effects of operational variables on pulp yield and lignin solubilization, Elsevier Science Ltd., Great Britain, Bioresource Technology, 58: 17-23.

26. Casey, J. P. (1980). Pulp and paper: Chemistry and chemical technology, Vol. I, $3^{\text {rd }}$ Edition, New York, John Wiley \& Sons.

27. Kleppe, P. J. (1970). Kraft pulping (feature review). TAPPI: Journal of the Technical Association of the Pulp and Paper Industry, 53(1): 35-47. 